\title{
Legal Liability for Violation of Romania's Legislation Regarding the Protection of Historical Monuments, an Integral Part of the National Cultural Heritage
}

\author{
Natalia Chiriac*, Viorica Ursu, Ina Bostan \\ Department of Engineering, Law and Real Estate Valuation, Technical University of Moldova, Chișinău, Moldova \\ Email: *natalia.chiriac@dp.utm.md
}

How to cite this paper: Chiriac, N., Ursu, V. and Bostan, I. (2021) Legal Liability for Violation of Romania's Legislation Regarding the Protection of Historical Monuments, an Integral Part of the National Cultural Heritage Open Access Library Journal, 8: e7475.

https://doi.org/10.4236/oalib.1107475

Received: April 29, 2021

Accepted: June 18, 2021

Published: June 21, 2021

Copyright $\odot 2021$ by author(s) and Open Access Library Inc.

This work is licensed under the Creative Commons Attribution International License (CC BY 4.0).

http://creativecommons.org/licenses/by/4.0/

\begin{abstract}
The loss of cultural property is irreparable and irreversible. Any disappearance of cultural heritage will inevitably affect all areas of the life of present and future generations will lead to spiritual impoverishment, ruptures in historical memory, and the ruin of society as a whole. They cannot be compensated either by the development of modern culture or by the creation of significant new works. The accumulation and preservation of cultural values is the basis for the development of civilization. The research topic is the analysis of Romanian legislation, which provides responsibility for the destruction or damage of history and culture monuments; the practice of applying these rules in the field of use and protection of monuments of history and culture; trends and ways of developing the legislation in this field; lastly, the problems of improving the criminal and contravention legislation on this subject. There are a series of norms of criminalization of some antisocial behaviors in the field of protection of the immovable national cultural heritage in the legislation in force. Thus, the central objective of this study is to systematically present the rules that correspond to this description.
\end{abstract}

\section{Subject Areas}

Law

\section{Keywords}

Legal Liability, Cultural Heritage, Real Estate, Historical Monument, Cultural Values, Crime 


\section{Introduction}

From the outset, it is necessary to clarify the subject of this study. The Romanian legislation and doctrine distinguish the following areas of national cultural heritage: immovable national cultural heritage (historical monuments), archaeological heritage, national movable cultural heritage, and intangible national cultural heritage [1].

According to article 1 paragraph (2) of the Romanian Law no. 422/2001 on the protection of monuments, "historical monuments are real estate, constructions and lands located on the territory of Romania, significant in the history, culture and national and universal civilization [2]."

The legal regime for the protection of the cultural heritage must be specified in the urbanism certificate of the respective good. The urbanism certificate is issued at the request of any applicant, natural or legal person, who may be interested in knowing the data and regulations to which the property is subject, in accordance with Law no. 350/2001 on spatial planning and urbanism, republished, with subsequent amendments and completions. The requests for the issuance of the urbanism certificate are addressed to the authorities provided in article 4 and to article 43 lit. (a) of Law no. 50/1991 regarding the authorization of the execution of the republished construction works, with the subsequent modifications and completions [3]. Information on the legal regime for the protection of cultural heritage can be obtained from the county directorates for culture, respectively Bucharest's Directorate for Culture (decentralized public services of the Ministry of Culture), given the provisions of article 6 paragraph (1) lit. (e) of article 16 lit and (a) points 2, 14, 18 of the Organization and Functioning Regulation approved by OMCPN no. 2080/2012. Another source of information is the National Institute of Heritage, given that it prepares and periodically updates the List of Historical Monuments ${ }^{1}$.

At present, the list of historical monuments in Romania (LHM), which was updated on the situation in 2015, constitutes 30,448 historical monuments (Table 1).

Six cultural sites: (churches in Moldova, Horezu Monastery, villages with fortified churches in Transylvania, Dacian fortresses in the Orăștie Mountains, the historic center of Sighișoara and wooden churches in Maramureș) and two natural sites (Danube Delta and the secular and virgin beech forests of the Carpathians and other regions of Europe) are currently included in the UNESCO World Heritage in Romania ${ }^{2}$.

Table 1 elaborated by the author according to Lista monumentelor istorice $(2015)^{3}$.

The practical research significance of the research lies in the comparative analysis of the legislation in the field by determining the strengths and gaps, so ${ }^{1}$ Patrimoniu cultural imobil. http://www.cultura.ro/intrebari-frecvente

${ }^{2}$ Lista Patrimoniului Mondial-UNESCO. https://patrimoniu.ro/monumente-istorice/lista-patrimoniului-mondial-UNESCO vizitat: 11.04.2021 ${ }^{3}$ Lista monumentelor istorice, 2015.

https://patrimoniu.ro/images/lmi-2015/lista-monumentelor-istorice-2015.pdf 
Table 1. The list of historical monuments in Romania (LHM), on the situation in 2015.

\begin{tabular}{cccccc}
\hline $\begin{array}{c}\text { Administrative } \\
\text { centre }\end{array}$ & $\begin{array}{c}\text { Nr. } \\
\text { of historical } \\
\text { monuments }\end{array}$ & $\begin{array}{c}\text { Administrative } \\
\text { centre }\end{array}$ & $\begin{array}{c}\text { Nr. of } \\
\text { historical } \\
\text { monuments }\end{array}$ & $\begin{array}{c}\text { Administrative } \\
\text { centre }\end{array}$ & $\begin{array}{c}\text { Nr. of } \\
\text { historical } \\
\text { monuments }\end{array}$ \\
\hline Alba & 686 & Constanța & 694 & Mureș & 1018 \\
Arad & 417 & Covasna & 594 & Neamț & 537 \\
Argeș & 1022 & Dâmbovița & 1237 & Olt & 758 \\
Bacău & 366 & Dolj & 700 & Prahova & 1073 \\
Bihor & 455 & Galaţi & 263 & Sălaj & 546 \\
Bistriţa Năsăud & 172 & Giurgiu & 540 & Satu Mare & 310 \\
Botoșani & 768 & Gorj & 503 & Sibiu & 1053 \\
Brăila & 510 & Harghita & 742 & Suceava & 518 \\
Brașov & 986 & Hunedoara & 518 & Teleorman & 393 \\
București & 2651 & Ialomița & 227 & Timiș & 340 \\
Buzău & 869 & Iaşi & 1634 & Tulcea & 574 \\
Călărași & 285 & Ilfov & 730 & Vâlcea & 791 \\
Caraș Severin & 832 & Maramureș & 610 & Vaslui & 438 \\
Cluj & 1791 & Mehedinți & 870 & Vrancea & 427 \\
Total: & & & 30,448 & & \\
\hline & & & & & \\
\hline & & & & & \\
\hline
\end{tabular}

that later through the analogical and comparative method we can propose new changes in this area in the national legislation.

Considering the objective of this research, the Article was divided into $7 \mathrm{sec}-$ tions, which reflect the analysis of Romanian legislation on the issue addressed, research in the field at the current stage of development, presentation of the analysis of judicial practice, and personal opinion of the author. The introductory part of the article is the scientific argumentation of the research topic, made by exposing the topicality and importance of the research topic, the degree of research, purpose, and objectives proposed for implementation. In Section 2, the obtained results and discussions are being investigated Romanian's regulatory and case law framework in the area of responsibility for the destruction or damage of history and cultural monuments. Sections $3-6$ fully analyze the constitutive content of the offenses/contraventions provided in the following normative acts: The Criminal Code of Romania from July 17, 2009, Law no. 422/2001 on the protection of historical monuments, Law no. 50/1991 regarding the authorization of construction works, Romania's government Ordinance no. 47 from January 30, 2000 on the establishment of measures for the protection of historical monuments that are part of the World Heritage List. And Section 7 has the final conclusions that have been drawn from the research.

\section{The Obtained Results and Discussions}

Constitutional Bases: The constitutional pillars of legal protection of Romania's cultural heritage are represented by the recognition and guarantee by the Fun- 
damental Law of December 8, 1991 of access to culture (revised) (article 33), the right to education (article 32), and the right to a healthy environment (article 35). Undoubtedly, other constitutional provisions, directly or indirectly, have implications for this. This is the case, for example, of the provisions of article 44 paragraph (7), regarding the tasks related to the right of private property, the defense of the values of human dignity, and the free development of the human personality (article 1), the obligation to exploit the natural resources in the national interest (article 135 paragraph (2) lit. (d)) or those of a technical nature concerning the relations between domestic law and international law (article 11), international treaties on human rights (article 20), the priority of EU law (article 148 paragraph (2)).

Criminal law has a significant role in protecting the most important social values, but in order to achieve the criminal law's objective to the greatest extent possible, these values must be well defined, and subject to a well-designed legal regime. Thus, we consider that it is essential for the criminal law to be an instrument for protecting the national cultural heritage in Romania, because the social realities demonstrate the special gravity of the criminal phenomenon in this field, as well as the persistence in criminal behavior and even some serious forms of manifestation by committing this type of crime.

The crime against cultural heritage is a term that refers to illegal actions against works of art, historical monuments, or archaeological sites [4].

The destruction or degradation of cultural heritage means the disappearance of the memory and cultural identity of a state's citizens, consequently, the inability to pass on this heritage to future generations [5].

Thus, we conclude that by offenses against the historical and cultural heritage are meant those socially dangerous actions, provided for and prohibited by the criminal law, which violate the relations regarding the use and conservation of the cultural heritage objects (historical and cultural monuments), mobile cultural values, places of concentration of cultural values (archives, museums, libraries), intangible cultural heritage [6].

Currently, the Romanian legislation provides several norms regarding the protection of the immovable national cultural heritage, among which we can mention:

1) The Criminal Code of Romania from July 17, 2009;

2) Law no. $422 / 2001$ regarding the protection of historical monuments;

3) Law no. 50/1991 regarding the authorization of construction works;

4) The government Ordinance No. 47/2000 on the establishment of measures for the protection of historical monuments that are part of the World Heritage List [7].

The offenses enshrined in the three normative acts have as a characteristic element the material object, represented by the buildings that are historical monuments. The facts that affect the historical monuments inscribed on the Wold Heritage List are under the incidence of the government Ordinance no. $47 / 2000[5]$. 
The Romanian criminal code in force includes the norms of incrimination with a general incidence on the goods that are part of the national cultural patrimony. As the present study is dedicated exclusively to the immovable cultural heritage, in the following part we will analyze only the crimes whose material object may constitute the immovable property, a component part of the cultural heritage.

\section{The Criminal Code of Romania from July 17, 2009}

\subsection{Article 253 CC, Destruction}

According to Article 253 of the Civil Code, Destruction:

“1) Destruction, degradation or rendering in a state of non-use of a property belonging to another person or preventing the taking of measures to preserve or save such property, as well as the removal of measures taken, shall be punishable by imprisonment from 3 months to 2 years or a fine;

2) The destruction of a document under private signature, which wholly or partly belongs to another person and serves to prove a right of patrimonial nature, but doing this has led to damage, shall be punished with imprisonment from 6 months to 3 years or fine;

3) If the deed provided in paragraph (1) concerns the goods that are part of the cultural heritage, the penalty is imprisonment from one to 5 years;

4) The destruction, degradation or rendering in a state of non-use of a good, committed through arson, explosion or through any other means and if it is likely to endanger other people or property, shall be punished by imprisonment from 2 to 7 years;

5) The provisions provided in paragraph (3) and paragraph (4) shall be applied even if the property belongs to the perpetrator;

6) For the facts provided in paragraph (1) and paragraph (2) the criminal action is initiated upon the prior complaint of the injured person;

7) The attempt of the facts provided in paragraph (3) and paragraph (4) shall be punished."

It follows, therefore, from the definition given to destruction that by this offense the physical, material integrity and the possibility of using a good or a patrimonial value that is part of the property of their natural or legal person is harmed. Therefore, the text of the law provides for a standard variant and three aggravated variants. Considering the object of the present study, we will refer only to 2 aggravating variants-paragraphs 3 and 4 .

a) The aggravated variant provided by article 253 paragraph (3) of the Criminal Code

Notion: According to article 253 paragraph (3) of the Criminal Code, the deed consists in the destruction, degradation, or rendering in a state of non-use of the goods that are part of the cultural heritage.

The legal object of the crime provided in article 253 paragraph (1) of the Criminal Code consists in the patrimonial social relations regarding the assurance of the existence and physical, material integrity of the goods that are part of 
the property of the natural or legal persons, as well as in the protection and intangibility of the material integrity of this property [8].

The material object of this aggravated form concerns the goods that are part of the cultural heritage, in our situation, it is the real estate, belonging to the cultural heritage, on which the illicit action is directed. In the case of historical monuments: "the real estate, constructions and lands located on the Romanian territory, significant for the history and culture and national and universal civilization 422" are exclusively the material object (article 1 paragraph (2)), damaged by actions of partial or total destruction, expropriation without the approval of the Ministry of Culture, degradation, desecration or disturbance of possession. The historical monument regime is conferred by classifying these real estates according to the procedure provided by law. "Real estate located outside the borders, properties of the Romanian state, may be classified as historical monuments, in compliance with the state legislation on whose territory it is located (article 1 paragraph (4))" [1].

It is important to mention the fact that the aggravation provided in article 253 paragraph (3) CC assumes, that the respective property has a certain legal status, proven by documents issued by the authorities, from which it results that it is part of the cultural heritage, but the text does not specify, it may be national or world cultural heritage goods [9].

It is necessary for the good to be valuable and likely to be damaged either in its substance or in terms of its potential use. It does not matter if the good is in perfect condition, or it has a certain degree of wear. The goods without any value and the abandoned goods cannot constitute a material object of the crime [8].

Analyzing the objective side of the crime provided in article 253 paragraph (3) CC, we mention that its material element consists in an alternative action of:

$\checkmark$ destruction, degradation, or rendering in a state of non-use of a good belonging to another person;

$\checkmark$ preventing the taking of measures for the conservation or saving of such an asset;

$\checkmark$ removal of the measures taken.

According to the judicial theory and practice, degradation consists of damage to the property, so that it has lost some of its qualities, which has led to a reduction in its potential for use, there is degradation when the deed affects the aesthetics of the property ${ }^{4}$, as well as when the good can be given another destination.

The destruction consists in damaging the substance of the good in such a way that it ceases to exist in its materiality (demolition of a construction). Some authors consider that the destruction, as such, has extremely vague limits, ${ }^{4}$ Infracțiunea de distrugere prin inacțiune. Subiectul activ-acționarul majoritar al unei societăți în proprietatea căreia se afla bunul degradat. Prejudiciul ca urmare imediată și condiție a răspunderii civile delictuale. Cauzele modificatoare de pedeapsă. Aplicarea pedepsei închisorii cu executare în regim privativ de libertate. Restabilirea situației anterioare săvârşirii infracțiunii. http://revistaprolege.ro/infractiune-distrugere-prin-inactiune-subiectul-activ-actionar-majoritar-soc ietati-in-proprietatea-careia-se-afla-bunul-degradat-prejudiciul-ca-urmare-imediata-si-conditie/ 
especially in relation to a cultural asset where, at times, the destruction of cultural value could even be excessive cleansing (for example, the polishing of ancient coins can significantly diminish both cultural and commercial value; repainting a fresco with irreversible materials and techniques can lead to its destruction) [10].

By rendering the good a state of non-use supposes putting the good in the situation of not being able to be used, temporarily or permanently, in relation to its destination, but by other means than those of destruction or degradation. Thus, rendering the good a state of non-use represents the most significant change of an object or parts of it, for example, the removal of fragments. If damaged, the object cannot be used for its intended purpose without restoration. Such damage should also be visible to non-specialists. A monument of history or culture will not be affected for the purposes of this article if the inscriptions, drawings, fragments that are difficult to remove, etc. are painted [6].

Preventing the taking of measures to preserve or save an asset is an indirect way of destroying the asset; the perpetrator does not act directly on it to destroy it, but he does not take measures to protect it from the danger of destruction that threatens it (for example, preventing the digging of a ditch to divert the waters of a torrent that could collapse the wall of a house, preventing extinguishing a fire in one's own household) [8].

The removal of the conservation or rescue measures taken means the situation in which, following the measures to protect the property from the danger of destruction that threatens it, the perpetrator removes these measures (for example, the removal of the supporting pillars of a fence or wall which is going to collapse).

Each of these alternative ways of committing the crime can be committed by action (commission) or inaction (omission), as well as in any way, by any procedure and by any means (either the perpetrator's own physical force or the use of certain means suitable for physical, mechanical, chemical, etc.). Committing several of these actions against the same good, even successively, or against several goods simultaneously, meets the constitutive elements of a single crime. However, if the deed is committed through arson, explosion or any other such means and results in public danger, the crime is more serious, according to article 253 paragraph (4) of the Criminal Code.

There must be a causal link between the harmful outcome and the act of destruction (in any of the ways listed). Therefore, the destruction of property is a resultant crime.

In the case of this variant, the active subject can be any person, but also the asset's owner that forms the material object.

The subjective side: The crime of destruction, in the aggravated version, is committed intentionally, which can be direct or indirect.

The attempt, in the case of this variant, is punished (article 253 paragraph (7) of the Criminal Code).

The sanction: The offense provided by article 253 paragraph (3) of the Crimi- 
nal Code shall be punished with imprisonment from one to 5 years.

Procedural aspects: The criminal action is initiated ex officio.

b) The aggravated variant provided by article 253 paragraph (4) of the Criminal Code

Notion: According to article 253 paragraph (4) of the Criminal Code, the deed is more serious if the destruction, degradation or rendering in a state of non-use of a good is committed by fire, explosion, etc., likely to endanger other people or goods.

The objective side: The material activity can be accomplished through a plurality of facts or alternative ways. Thus, ignition means the triggering of a physico-chemical phenomenon that causes the combustion of combustible substances in the presence of oxygen in the air. Fires can be caused immediately or later. Explosion involves the triggering of the destructive energy of an explosive material on one or more assests.

Other such means can be considered any material operations likely to trigger a strong destructive energy, such as the opening of a barrage that caused floods, etc.

And in this case, the crime can be committed only by destruction, degradation or rendering in a state of non-use. Any of these actions must be committed through fire, explosion or any other such means. From the enumeration made in the text, which is not limited, it results that these are means that by themselves present social danger. Finally, the act must be in public danger. The public danger must occur in an effective sense, not only the possibility of its occurrence being sufficient [11]. In this case, the destruction has the character of a crime of endangerment, because it is conditioned by the endangerment of an indeterminate number of goods and people 5 . The deed constitutes a crime, even if the property belongs to the perpetrator (article 253 paragraph (5) CC).

The use of these means aggravates the deed only if a public danger has resulted, i.e. an indeterminate number of goods have been exposed to destruction, at the same time endangering the life, people's bodily integrity or health [12].

Another condition imposed by the new Criminal Code regarding the objective side of the crime provided by article 253 paragraph (4) of the Criminal Code refers to the phrase "if it is likely to endanger other people or property". In this respect, in judicial practice it was decided, under the rule of the old Criminal Code, that the public danger must occur effectively, not only the possibility of its production being sufficient. The legislator's renunciation of the notion of public danger and its replacement with the phrase "likely to endanger other people or property" is commendable from the perspective of the need to respect the principle of legality of incrimination [11].

The attempt, in the case of this variant, is punished (article 253 paragraph (7) $\mathrm{CC})$.

The sanction: The offense provided by article 253 paragraph (4) of the Crimi${ }^{5}$ Trib. Suprem, dec. Nr. 853/1973, În R.R.D., nr. 10/1974, p. 58. 
nal Code shall be punished by imprisonment from 2 to 7 years.

Procedural aspects: The criminal action is initiated ex officio.

\subsection{Article 254 of the Criminal Code, Qualified Destruction}

Notion, according to article 254 of the Criminal Code:

"1) If the facts provided in article 253 resulted in a disaster, the penalty is imprisonment from 7 to 15 years and a ban on exercising certain rights.

2) The disaster consists in the destruction or degradation of some immovable goods or of some works, equipments, installations or components thereof, and which resulted in the death or bodily injury of two or more people."

This crime constitutes a more serious variant of the destruction of goods and can be committed in any of the ways provided in article 253 of the Criminal Code, but whose specific result is the occurrence of a disaster.

The disaster, therefore, involves, first and foremost, the destruction or degradation of immovable property or of works, equipment, installations or components thereof, and which has resulted in the death or personal injury of two or more people.

Secondly, the disaster involves the death or injury of the bodily integrity of two or more people. If none of these consequences occurred, the deed does not constitute qualified destruction, but falls, as the case may be, in one of the paragraphs of article 253 of the Criminal Code.

Finally, the disaster involves the perpetrator's fault in terms of causing people's death or personal injury, outside his intention in terms of committing the act of destruction or degradation. Thus, the destruction that resulted in the disaster is a premeditated crime. If the perpetrator acted intentionally regarding the occurrence of people's death or personal injury, the provisions of article 254 of the Criminal Code, the committed deeds constituting a contest of crimes. In the case of intentional death of several people, the contest exists between the crime of destruction and the qualified murder provided in article 189 paragraph (1) lit. (f) of the Criminal Code (murder committed on two or more people) [8].

The sanction: The destruction that has resulted in a disaster is punishable by 7 to 15 years in prison and a ban on exercising certain rights.

\subsection{Article 255 of the Criminal Code, Destruction through Fault}

According to article 255 of the Criminal Code:

“1) The destruction, degradation or rendering in a state of non-use of a good through fault, even if it belongs to the perpetrator, shall be punished by imprisonment from 3 months to one year or by a fine; if the deed is committed through fire, explosion or by any other such means and if it is likely to endanger other people or property.

2) If the deeds resulted in a disaster, the punishment is imprisonment from 5 to 12 years."

As a general rule, the destruction through the fault of another person's property is not a crime, but only a civil offense that attracts civil liability. From this 
rule, the Criminal Code created derogation, in that it incriminated as a crime of destruction through fault those deeds which, by the means used, by the special kind of goods which form its material object, by special consequences or other circumstances of committing, is of sufficient importance to incur criminal liability. The name of "destruction through fault", article 255 of the Criminal Code incriminates both the simple variant and an aggravated variant.

a) The standard variant provided by article 255 paragraph (1) of the Criminal Code

Notion: According to article 255 paragraph (1) of the Criminal Code, the deed consists in the destruction, degradation or bringing into a state of non-use, through fault, of a good, even of the perpetrator, if it is committed through arson, etc. and if it is likely to endanger other people or property.

The material element of the crime is identical to the one from the intentional destruction in the aggravated form of article 253 paragraph (4) of the Criminal Code, to which we refer. The immediate consequence is the possibility of endangering other people or property, without the need for danger to occur.

There must be a causal link between the material activity and the immediate consequence.

It has been established in the judicial practice ${ }^{6}$ that, unless it has been established without doubt that the defendant left an electrical outlet plugged in and that this was the cause of the fire at a commercial complex, he/she cannot be charged with the crime of destruction through fault, even though it resulted in public danger.

The subjective side of the crime consists of guilt, in both forms.

The attempt and consumption: The attempt is not possible. The consummation of the crime takes place when the action of the perpetrator is carried out to the end, being likely to endanger other people or property.

The sanction: The offense provided by article 255 paragraph (1) of the Criminal Code shall be punished by imprisonment from 3 months to one year or a fine.

b) The aggravated variant provided by article 255 paragraph (2) of the Criminal Code

Notion: According to article 255 paragraph (2) of the Criminal Code, the crime is more serious if the deeds resulted in a disaster.

The offense provided by article 255 paragraph (2) of the Criminal Code, has the same content as the crime provided by article 254 paragraph (1) of the Criminal Code, with the difference that, from a subjective point of view, the deed is committed through fault.

The sanction: The offense provided by article 255 paragraph (2) of the Criminal Code shall be punished with imprisonment from 5 to 12 years.

\subsection{Article 443 of the Criminal Code, the Use of Prohibited Methods in Combating Operations}

"1. The act of a person who, in an armed conflict with or without an interna-

${ }^{6}$ C.A. Brașov, s. Pen., dec. Nr. 594/R/2006, în C.J.P. 2006, p. 93. 
tional character:

...(b) launches an attack by military means against the civilian property protected accordingly by the international humanitarian law, in particular the buildings dedicated to religious worship, education, art, science, charity, historical monuments, hospitals, places where the sick or wounded are gathered, and against the unauthorized cities, villages, dwellings or buildings or demilitarized zones or on installations or equipment containing dangerous substances, as they are not used as military targets...;

(h) uses the cultural property protected accordingly by the international humanitarian law, in particular the historical monuments, the buildings dedicated to religious worship, education, art or science, to launch an attack by military means against the enemy;

It is punishable by imprisonment from 7 to 15 years and a ban on the exercise of certain rights."

The legal object is the social relations that ensure the protection of civilians who do not participate directly in hostilities, their property and the environment. Good faith among combatants is also protected by banning treacherous means between them [11].

The material object is the people's body or the property affected by the military attack.

An active subject can be any person and criminal participation is possible in all forms.

The passive subject is the civilian population, but also the people protected by the international humanitarian law or the combatant forces, against which the forbidden fighting methods are used.

The objective side: The material element supposes several alternative ways of achieving the typicality of the deed, in our situation:

$\checkmark$ launches an attack by military means against the civilian goods protected accordingly by the international humanitarian law, especially the buildings dedicated to historical monuments;

$\checkmark$ uses the cultural goods protected accordingly by the international humanitarian law, especially the historical monuments.

The text of the law stipulates that, in order to achieve the typicality of the deed, the attack must be launched by any military means. These can be airplanes, battleships, armored vehicles, heavy artillery, military weapons grenades, etc.

Another condition that must be met for the typicality of the deed is that the attack, by military means, is aimed at the civilian population or the civilians who do not participate in hostilities. The alternative modalities also provide for the attack, by military means, to target the goods of special interest to the population, but also to the humanity in general.

The immediate consequence is the creation of a state of danger for the existence and security of the civilian population, of the goods protected by the international humanitarian law and even of the combatants. 
There must be a causal relationship between the material activity and the immediate consequence.

The immediate consequence is the creation of a state of danger for the existence and security of the civilian population, of goods protected by international humanitarian law and even of combatants.

There must be a causal relationship between the material activity and the immediate consequence.

The subjective side involves committing the act with direct or indirect intention.

The attempt and consumption: The attempt is punishable. The consummation of the crime takes place at the moment when the execution of the action is completed and the specific consequence is produced.

The sanction: The offense provided by article 443 paragraph (1) of the Criminal Code shall be punished by imprisonment from 7 to 15 years and the prohibition of exercising certain rights.

\section{Law No. 422/2001 on the Protection of Historical Monuments}

This law regulates the general legal regime of the historical monuments. According to the law, the historical monuments are real estate, constructions and lands located on the territory of Romania, significant for the history and culture and the national and universal civilization.

According to article 11 of Law no. 422/2001: 1) Any intervention on the historical monuments and on the buildings in their protection area, as well as any modification of the legal situation of the historical monuments shall be made only under the conditions established by this law; 2) The abolition, partial or total destruction, desecration, as well as the degradation of historical monuments are prohibited and are sanctioned according to the law.

The violation of the provisions of this law entails, as the case may be, civil, administrative, material, disciplinary, contraventional or criminal liability (article 53, Law no. 422/2001).

The sanctioning regime, in case of very serious facts, is at least unclear in Law $422 / 2001$. Thus, it is not obvious which punishment will be applied to the crimes directed against the historical monuments: the one from article 253 of the Criminal Code or that of article 24 paragraph (2) of Law 50/1991. It should be emphasized that Law 422 does not contain a specific punishment [11].

Article 55 of the Romanian law no. 422 from July 18, 2001 on the protection of historical monuments, provides a series of contraventions to the regime of historical monuments' protection, and the protected areas, among which we list:

1) The execution of works on a building after the start of the classification procedure, on a historical monument, in its protection area or in the protected areas without the approval of the Ministry of Culture or of its deconcentrated services, as the case may be;

2) The violation of the obligations provided in article $36^{7}$ by the owner or by 
the holder of the right to administer a historical monument;

3) Non-transferring the equivalent value of the stamp of the historical monuments, as well as of the taxes and tariffs provided by the present law;

4) The organization of the manifestations provided in article 9 paragraph (5) and $(6)^{8}$, without the agreement of the competent authority;

5) The non-specification in the urbanism certificate of the necessity of obtaining the approval of the Ministry of Culture and National Heritage or of its deconcentrated services, as the case may be, for the works proposed at historical monuments in their protection zone or in protected areas;

6) Issuing the building or demolition permits for works on historical monuments, in their protection areas or in the protected areas, without the approval of the Ministry of Culture or of the deconcentrated services, as the case may be.

The above-mentioned contraventions are prescribed within 3 years from the date of their commission and are sanctioned with a fine, the level of which can be updated by the Government's decision.

The contraventions are found and the fines are applied by the specialists of the county directorates for culture, cults and national cultural heritage, respectively, of Bucharest; by the proxies of the Ministry of Culture and National Identity; by the territorial inspectors of the State Construction Inspectorate or by the inspectors of the Ministry of Public Finance, as the case may be. For the contraventions provided in article 55 paragraph (1) lit. (1) and (2), the finding and application of fines may be made by the mayor, the president of the county council and their proxies or by the police, as the case may be (article 57) [1].

\section{Law No. 50/1991 Regarding the Authorization of Construction Works}

Article 24 of Law no. 50/1991 provides: 1) The following acts constitute offenses:

a) The execution, without a construction or demolition authorization, or with the non-observance of its provisions, of the works provided in article 3 lit. (b) ${ }^{9}$;

b) The continuation of the execution of the works after the order of their stopping by the competent control bodies, according to the law;

c) The elaboration or signing of technical projects, as well as of the projects for the authorization of the construction works' execution, for other specialties except those certified by the university diploma, under the conditions provided in the $9^{\text {th }}$ article.

\footnotetext{
${ }^{7}$ Article 36 stipulates the obligations of the owners of historic monuments.

${ }^{8}$ Article 9 (5) In the protected areas of the historical monuments that are places of worship, it is forbidden to carry out manifestations during the period in which the religious service is carried out, because through the sound or visual pollution that they produce, they can disturb the religious service, even though it takes place in the open area. (6) As an exception, the events such as those provided in par. (5), with the consent of the religious authority that administers the place, under the conditions that do not impede the conduct of the religious service.

${ }^{9}$ Article (3) lit. construction, reconstruction, extension, repair, consolidation, protection, restoration, conservation and any other works, whatever their value is, which are going to be carried out on the buildings representing historic monuments, including those in their protected areas, established according to the law.
} 
2) The offenses provided in paragraph (1) shall be punished by imprisonment from 3 months to 3 years or by a fine from 100 lei to 5000 lei.

We distinguish three types of distinct behaviors that they incriminate under distinct letters from the content of article 24, Law no. 50/1991. We agree with the points of view expressed in the specialty literature [13] which consider that the deeds provided by article 24 represent distinct crimes, not being in the presence of a crime with an alternative content. We base our solution on the wording used in the two paragraphs of the article, both referring to "crimes".

According to some opinions expressed in the specialty literature, it would be desirable that the crime in article 24 paragraph 1 lit. of Law no. 50/1991 to be found in Law no. 422/2001, the normative act that includes a complete regulation of the legal regime of historical monuments, which would allow an easier circumstance of the scope of application of this incrimination text [5].

The cumulative fulfillment of the following essential requirements is required for the existence of the objective side of this crime:

$\checkmark$ to commit one of the deeds listed by law: construction, reconstruction, extension, repair, consolidation, protection, restoration, conservation, or any other work on a construction.

$\checkmark$ the action on the construction to be among those for which the authorization is necessary.

$\checkmark$ the activity is unauthorized or is carried out in violation of the provisions of the authorization.

$\checkmark$ the construction should have the status of a historical monument.

\section{Romania's Government Ordinance No. 47 from January 30, 2000 on the Establishment of Measures for the Protection of Historical Monuments That Are Part of the World Heritage List}

This ordinance regulates the special measures for the protection of the historical monuments that are part of the World Heritage List. Thus, historical monuments that are part of the World Heritage List are meant the historical monuments from Romania inscribed in the World Heritage List by the World Heritage Committee attached to UNESCO.

Chapter IV of the government Ordinance no. 47/2000 is dedicated to sanctions. Thus, the violation of the provisions of this ordinance attracts, as the case may be, the civil, administrative, material, disciplinary, or contravention liability.

The abolition, partial destruction, or degradation of historical monuments that are part of the World Heritage List, are sanctioned according to the criminal law.

The following acts constitute contraventions, if they have not been committed in such conditions that they are considered crimes, according to the criminal law (Table 2).

The sanctions for the deeds provided in article 12 paragraph (1) shall be applied to natural and legal persons, as the case may be, according to the law. 
Table 2. The contraventions provided in Romania's government ordinance no. 47 from January 30, 2000.

\begin{tabular}{|c|c|c|}
\hline Name of the contravention & Sanction & $\begin{array}{l}\text { Authorities for establishing } \\
\text { and enforcing fines }\end{array}$ \\
\hline $\begin{array}{l}\text { a) the authorization of the construction } \\
\text { or demolition works in the buildings } \\
\text { with the regime of historical } \\
\text { monuments that are part of the World } \\
\text { Heritage List, without the approvals } \\
\text { provided in this ordinance; }\end{array}$ & $\begin{array}{l}\text { Fine } \\
\text { from } 2500 \text { lei } \\
\text { to } 15000 \text { lei }\end{array}$ & $\begin{array}{l}\text { territorial inspectors of the } \\
\text { State Inspection in Constructions, } \\
\text { Urbanism and Spatial Planning }\end{array}$ \\
\hline $\begin{array}{l}\text { b) construction, modification or } \\
\text { abolition of constructions in the } \\
\text { protection areas of historical monuments } \\
\text { inscribed in the World Heritage List, } \\
\text { without the approval of the Ministry } \\
\text { of Culture and, where appropriate, the } \\
\text { Ministry of Public Works, Transport and } \\
\text { Housing; }\end{array}$ & $\begin{array}{l}\text { Fine } \\
\text { from } 2500 \text { lei } \\
\text { to } 15000 \text { lei }\end{array}$ & $\begin{array}{l}\text { territorial inspectors of the } \\
\text { State Inspection in Constructions, } \\
\text { Urbanism and Spatial Planning }\end{array}$ \\
\hline $\begin{array}{l}\text { c) violation by the owner of the } \\
\text { obligations provided in the legislation } \\
\text { in force regarding the protection of } \\
\text { historical monuments; }\end{array}$ & $\begin{array}{l}\text { Fine } \\
\text { from } 2500 \text { lei } \\
\text { to } 15000 \text { lei }\end{array}$ & $\begin{array}{l}\text { specialists of decentralized } \\
\text { public services of the } \\
\text { Ministry of Culture }\end{array}$ \\
\hline $\begin{array}{l}\text { d) violation of the provisions of article } \\
6 \text { paragraph }(7)^{10} \text {, article } \\
\left.7 \text { paragraph }(1)^{11} \text { and of article } 9 \text { lit. e }\right)^{12} \text {; }\end{array}$ & $\begin{array}{l}\text { Fine } \\
\text { from } 1500 \text { lei } \\
\text { to } 5000 \text { lei }\end{array}$ & $\begin{array}{l}\text { specialists of decentralized } \\
\text { public services of the } \\
\text { Ministry of Culture }\end{array}$ \\
\hline $\begin{array}{l}\text { e) violation of the provisions of article } \\
8 \text { paragraph }(2)^{13} .\end{array}$ & $\begin{array}{l}\text { Fine } \\
\text { from } 1500 \text { lei } \\
\text { to } 5000 \text { lei }\end{array}$ & $\begin{array}{l}\text { territorial inspectors of the } \\
\text { State Inspection in Constructions, } \\
\text { Urbanism and Spatial Planning }\end{array}$ \\
\hline
\end{tabular}

\section{Conclusions}

The analysis of legislation, doctrinal sources and materials of judicial practice allows us to conclude that one of the most effective methods of protecting historical and cultural monuments is to establish the responsibility for their damage or destruction.

The offenses against the historical and cultural heritage mean those socially

${ }^{10}$ Article 6. (7) The buildings of historic monument or the fences of the sites that are part of the World Heritage List are marked, by the mayor of the locality, with the logo "Historic monument inscribed in the World Heritage List", presented in the annex that is an integral part of this ordinance. ${ }^{11}$ Article 7. (1) The urban planning and spatial planning documents for the areas comprising the historic monuments that are part of the World Heritage List and their protection areas shall be elaborated or updated by including the urban planning provisions and regulations and the spatial planning from the management and protection programs, within 12 months of the program approval.

${ }^{12}$ Article 9. In order to protect the historic monuments that are part of the World Heritage List and to comply with the legal provisions in this field, the local public administration authorities have the following main attributions: e) take the necessary technical and administrative measures to prevent the degradation of historic monuments from the World Heritage List, in collaboration with the decentralized public services of the Ministry of Culture.

${ }^{13}$ Article 8. (2) The title is inscribed, by the mayor of the locality, on the panels located at the entrances to the locality, the size of those with the name of the locality, in white letters on a brown background, and it is accompanied by the world heritage logo. 
dangerous actions, provided for and prohibited by the criminal law, which violate the relations regarding the use and conservation of the cultural heritage objects (historical and cultural monuments), mobile cultural values, places of concentration of cultural values (archives, museums, libraries), intangible cultural heritage [6].

There is a clear ineffectiveness of the current sanctioning measures. The treatment of responsibilities and sanctions is completely superficial, a special relevance being the case of Law 422/2001 on the protection of historical monuments. This law does not provide for any crime on its own, referring to the Criminal Code, especially for the crime of destruction, provided by article 253 of the Criminal Code. It should be emphasized here that the crime of destruction manifests itself in terms of the subjective side, intentionally, a situation that limits the area of investigations on cases that harm cultural heritage. Another limitation of the criminal law is that of determining the penalties according to material damage that can be quantified. The damage of the cultural heritage has a dimension that cannot be associated only with the material value. This material value can often be insignificant in relation to the cultural one. The reduction of the punishment limits in the new Penal Code, accompanied by a deficient level of education, cannot discourage the facts that affect the national cultural heritage [10].

Moreover, the government Ordinance no. 47/2000 does not contain a specific sanction. The law enforcement methodologies are not completed or correlated with other laws in force (Public Finance Law, Local Public Finance Law, Public Procurement Law, Criminal Code, Fiscal Code, Labor Code, Sponsorship Law, etc.) [14].

Therefore, by adopting the Romanian Heritage Code, some economic pressures will be anticipated, so that the needs of heritage protection and enhancement do not conflict with the financial procedures and the results pursued mainly in terms of profitability or fairness of funding programs [10].

The forward-looking research plan for the subject shall be directed toward continuing investigations on responsibility for the destruction or damage of history and culture monuments, the practice of applying these rules in the field of use and protection of historical and cultural monuments, trends, and ways of developing legislation in this field, and last but not least, the problems of improving the criminal and contravention legislation on this subject in the Republic of Moldova, based on the positive experiences of other states.

We also propose to study in more detail the practice of the judiciary in order to detect shortcomings in the application of the provisions of both national and foreign legislation in force.

\section{Funding Note}

This Research Paper was written within the Research project: Increasing the value of architectural heritage of R. Moldova 20.80009.0807.34. 
One of the objectives of the research project is the comparative analysis of national and international regulations and policy initiatives on the protection and enhancing of architectural heritage. The main objective in this case, no doubt, must be the corresponding amendment of the national legislation in force.

The state of Romania was not chosen at random: it is a country that is part of the Romanian-German law system and, therefore, we can find much in common regarding the legal technique, the construction of laws, etc. Moreover, often R. Moldova borrows from Romania the experience of drafting legislation.

And last but not least, both Romania and the Republic of Moldavia have a common cultural history, a history that has been and still is the basis of the architectural heritage, a history that also marked us descendants of this Dacian people!

\section{Conflicts of Interest}

The authors declare no conflicts of interest regarding the publication of this paper.

\section{References}

[1] Duțu, M., Lazăr, A. and Predescu, O.V. (2018) Protecția juridică a patrimoniului cultural și natural: volum dedicat Centenarului Marii Uniri și Anului European al patrimoniului cultural. Bucureşti: Editura Academiei Române, Universul Juridic, Bucureşti, $350 \mathrm{p}$.

[2] (2006) Law No. 422/2001 Regarding the Protection of Historical Monuments. Official Gazette (M.O.), Romania. http://legislatie.just.ro/Public/DetaliiDocument/29761

[3] (2004) Law No. 50/1991 Regarding the Authorization of the Execution of the Republished Construction Works. Official Gazette (M.O.), Romania. http://legislatie.just.ro/Public/DetaliiDocument/55794

[4] Drabineac Ion. (2021) Patrimoniul cultural din România între infracțiune și protejare, Târgoviște. https://www.scoaladoctorala.valahia.ro/wp-content/uploads/2020/12/rezumat-tezade-doctorat-drabineac.pdf

[5] Chrisanta-Daniela Nichifor. (2009) Protecția penală a patrimoniului cultural național. Rezumatul tezei de doctor, București, 61 p.

[6] Chiriac, N., Ursu, V. and Bostan, I. (2020) Răspunderea pentru încălcarea legislației privind protecția patrimoniului cultural imobil al Federației Ruse. În Problematica patrimoniului arhitectural în Republica Moldova. Evaluarea imobilului conform standardelor internaționale de evaluare: Materialele Seminarului Științific național, 77-89

[7] (2000) The Government Ordinance No. 47/2000 on the Establishment of Measures for the Protection of Historical Monuments that Are Part of the World Heritage List. Official Gazette (M.O.), Romania. http://legislatie.just.ro/Public/DetaliiDocument/20779

[8] Bodea, R. and Bodea, B.G. (2018) Drept penal. Partea specială. Hamangiu, Drept penal. Partea specială (lege5.ro), 62 p.

[9] Florin, S. (2010) Instituții și infracțiuni în Noul Cod penal. București. 
https://ro.scribd.com/doc/209617280/Institutii-Si-Infractiuni-in-Noul-Cod-Penal-S treteanu

[10] Tezele prealabile ale codului patrimoniului cultural. http://www.cultura.ro/sites/default/files/inline-files/TEZE_PREALABILE_CODUL_ PATRIMONIULUI_fin041016.pdf

[11] Bogdan, S., Șerban, D.A., Zlati, G. (2014) Noul Cod Penal. Partea specială. Analize. Explicații. Comentarii. Perspectiva clujeană. Universul Juridic, București.

[12] Dongoroz, V., Khane, S., Oancea, I., Fodor, I., Iliescu, N., Bulai, C., Stănoiu, R.M. and Roșca, V. (1972) Explicații teoretice ale Codului penal român. Partea specială, vol III. Academiei, București.

[13] (2009) Raportul Comisiei Prezidențiale pentru Patrimoniul Construit, Siturile Istorice și Naturale.

https://media.hotnews.ro/media_server1/document-2009-10-7-6253621-0-raportulcomisiei-prezidentiale-pentru-patrimoniul-construit.pdf

[14] Almaş, S. (2008) Infracțiunile prevăzute de article 24 din Legea nr. 50/1991 privind autorizarea executării lucrărilor de construcții. Caiete de Drept Penal, nr. 1. 